\title{
The Role of Fibroscan as a Non-Invasive Predictor for Oesophageal Varices in Post HCV Cirrhotic Egyptian Patients With or Without Bilhariziasis
}

\author{
Mohamed Bastawy ${ }^{1}$, Anwar Gomaa El-Sheety ${ }^{1}$, Ahmed Abd El-Aleem ${ }^{1}$, Yasser M. M. El-Dessouky ${ }^{1}$, \\ Ayman Rabie ${ }^{2}$ and Sherif Mohammad El-sayed Amine Hegab ${ }^{2}$ \\ ${ }^{1}$ Tropical Medicine Department, Faculty of Medicine, Al-Azhar University \\ ${ }^{2}$ Hepatology Department, Ahmed Maher Teaching Hospital, Cairo, Egypt. \\ Corresponding author: Sherif Hegab, E-Mail: sherifhegab1@yahoo.com, Mobile: 01006502052
}

\begin{abstract}
Background: Development of oesophageal varices is a major complication that may occur in up to $90 \%$ of cirrhotic patients. The endoscopic screening is an invasive procedure. This is why the selection of patients with large oesophageal varices at high risk for bleeding has become an issue of growing importance. In this respect, several clinical, biochemical, ultrasonographic and elastrogarphic (transient elastography-TE) methods have been proposed (and some of them validated) as noninvasive alternatives to endoscopy.

Objectives: It was to evaluate transient elastography by fibroscan in the prediction and determination of the grade of esophageal varices in cirrhotic patients due to chronic hepatitis c virus (HCV) infection with or without bilharziasis.

Patients and Methods: Sixty Egyptian patients with body mass index (BMI) <35, no history of: upper gastrointestinal tract (GIT) bleeding, hepatocellular carcinoma, moderate and tense ascites or any other cause of liver cirrhosis. The patients were divided into two groups: Group I included thirty patients with liver cirrhosis due to $\mathrm{HCV}$ infection only. Group II included thirty patients with liver cirrhosis due to HCV infection associated with bilharziasis. The patients were subjected to: 1) Thorough history taking. 2) Detailed clinical examination. 3) Laboratory tests. 4) Abdominal ultrasound. 5) Rectal snip for diagnosis of bilharziasis. 6) Upper gastrointestinal endoscopy. 7) fibroscan.

Results: Regarding fibroscan in both groups, the mean values of fibroscan were lower in patients without esophageal varices than patients with esophageal varices or with large esophageal varices with statistically high significant differences $(\mathrm{p}<0.01)$. Regarding fibroscan in group $\mathrm{I}$, the mean values of fibroscan were lower in patients without esophageal varices than patients with small esophageal varices with statistically high significant differences $(\mathrm{p}<0.01)$. But in group II, the mean values of fibroscan were lower in patients without esophageal varices than patients with small esophageal varices with statistically non significant differences ( $p$ $>0.05$ ). In both groups, the mean values of fibroscan were lower in patients with small esophageal varices than patients with large esophageal varices with statistically non significant differences ( $p>0.05)$.

Conclusion: fibroscan is valuable in predicting the presence of esophageal varices and large esophageal varices in patients with post HCV liver cirrhosis with or without bilharziasis but couldnot predict the grade of esophageal varices.
\end{abstract}

Keywords: Fibroscan, Liver stiffness, Esophageal varices, Grading, Non-invasive methods, liver cirrhosis.

\section{INTRODUCTION}

Cirrhosis is a condition prone to multiple complications because of portal hypertension. Variceal bleeding is a life threatinig event that has an incidence of $5 \%$ in Patients with small oesophageal varices and up to $15 \%$ in those with large oesophageal varices. Mortality per bleeding episode is around $10 \%-20 \%{ }^{(\mathbf{1})}$. Therefore, screening for esophageal varices in cirrhotic patients is a strong recommendation in all consensus statement (2). The current screening method is endoscopy at 23 years in patients without oesophageal varices and at 1-2 years in those with small varices but this approach is invasive. This is why the selection of patients with large oesophageal varices at high risk for bleeding has become an issue of growing importance. In this respect, several clinical, biochemical, ultrasonographic and elastrogarphic (transient elastography- TE) methods have been proposed (and some of them validated) as noninvasive alternatives to endoscopy ${ }^{(3)}$. Transient elastography is measured by Fibroscan (Echosens, Paris, France), equipped with a probe consisting of an ultrasonic transducer inducing vibration that cause an elastic shear wave that Propagates through the tissue. In the mean time, pulse-echo ultrasonic acquisitions are performed to follow the progression of the shear wave and measure its velocity, which is directly related to tissue stiffness. TE was proved to be useful in assessing the presence of significant fibrosis in patients with chronic hepatitis and in suggesting the presence of cirrhosis ${ }^{(4)}$. Many studies showed that liver transient elastography could predict the presence of oesophageal varices with conflicts around detection of its size ${ }^{(5)}$. 


\section{AIM OF THE WORK}

The aim of this study was to evaluate transient elastography by fibroscan as a noninvasive technique in the prediction and determination of the grade of esophageal varices in cirrhotic patients due to chronic hepatitis $\mathrm{C}$ virus infection with or without bilharziasis.

\section{PATIENTS AND METHODS}

After approval of ethical committee of $\mathrm{Al}-$ Azhar school of medicine, this study was conducted on sixty Egyptian patients. The patients were divided into two groups: Group I included thirty patients with liver cirrhosis due to HCV infection only. Group II included thirty patients with liver cirrhosis due to HCV infection associated with bilharziasis.

Inclusion criteria: Liver cirrhosis due to $\mathrm{HCV}$ infection with or without bilharziasis, no history of upper GIT bleeding or hepatocellular carcinoma and $\mathrm{BMI}<35$.

Exclusion criteria for the recruited patients: Other causes of liver cirrhosis, moderate and tense ascites, history of upper GIT bleeding and hepatocellular carcinoma.

\section{Methods:}

After getting a written consent, all the patients were subjected to: 1) Thorough history taking, 2) detailed clinical examination, 3) laboratory tests: Complete blood count, complete liver profile including (ALT, AST, prothrombin time, prothrombin concentration, total bilirubin, direct bilirubin and serum albumin), alpha fetoprotein, $\mathrm{HCV} \mathrm{Ab}, \mathrm{HBs} \mathrm{Ag}$, HCV RNA by real time PCR, ANA, ESR. Serum iron, serum ferritine, serum ceruloplasmin and serum bilharzial antibody titre, 4) Abdominal ultrasound, 5) Rectal snip for diagnosis of bilharziasis. 6) Upper gastrointestinal endoscopy using Pentax EG-3440 videoscope system] Classification of oesophageal varices $(\mathrm{OV})$ was done according to Bloom et al ${ }^{(6)}$ : None, small oesophageal varices $(\leq 5 \mathrm{~mm})$ and large oesophageal varices $(>5 \mathrm{~mm})]$ and 7) fibroscan.

\section{Fibroscan:}

To detect the degree of liver stiffness using $\mathrm{M}$ probe of $3.5 \mathrm{MHz}$ with depth of measurement from $25 \mathrm{~mm}$ to $65 \mathrm{~mm}$. The technique was performed by the same gastro-enterologist. Measurements were performed on the right lobe of the liver through the intercostals spaces on patients lying in the dorsal decubitus position with the right arm in maximal abduction. For each patient, the obtained elasticity value is the median of several measurements (usually 10 with a success rate of at least $60 \%$ and expressed as kilopascals, $\mathrm{kPa}$ ) was kept as representative of the liver elastic modulus.

The relation between fibroscan reading in $\mathrm{K}$ Pascal and the stage of fibrosis was clarified by Vizzuti ${ }^{(7)}$ as following: Fo (0:2.9), F1 (3:5.9), F2 (6:8.9), F3 (9:16.9) and F4 (17:75).

\section{Statistical analysis:}

Data were analyzed using IBM $\odot$ SPSS $\odot$ Statistics version 23 (IBM $\odot$ Corp., Armonk, NY). Normally distributed numerical data were presented as mean and SD and categorical data as number and percentage. Betweengroup comparisons of normally distributed numerical data was done using the Independent $t$ test.

\section{RESULTS}

Table (1): Comparison between group I and group II regarding fibroscan

\begin{tabular}{|c|c|c|c|c|}
\hline & Group I (N=30) & Group II (N=30) & \multicolumn{2}{|c|}{ Independent t-test } \\
\cline { 2 - 5 } & Mean \pm SD & Mean \pm SD & t & p-value \\
\hline Fibroscan $(\mathrm{KPa})$ & $37.12 \pm 8.92$ & $28.76 \pm 10.14$ & $\mathbf{3 . 3 9 1}$ & $\mathbf{0 . 0 0 1} * *$ \\
\hline
\end{tabular}

$$
* * \mathrm{P}<0.01: \mathrm{HS}
$$

Group I had a higher mean for fibroscan values with a high statistical significant difference than group II $(\mathrm{p}<0.01)$.

Table (2): Correlation between fibroscan and the studied parameters in group I.

\begin{tabular}{|c|c|c|}
\hline & \multicolumn{2}{|c|}{ Fibroscan (KPa) } \\
\hline & $\mathbf{r}$ & p-value \\
\hline Age (years) & -0.071 & 0.715 \\
\hline $\mathrm{Hb}(\mathrm{g} / \mathrm{dl})$ & 0.083 & 0.661 \\
\hline $\mathrm{RBCs}\left(\mathrm{x} 10^{\wedge} 6 \mathrm{cell} / \mathrm{cmm}\right)$ & 0.062 & 0.746 \\
\hline WBCs $(/ \mathrm{cmm})$ & -0.157 & 0.409 \\
\hline PLTs $\left(x 10^{\wedge} 3 / \mathrm{cmm}\right)$ & $-0.389 *$ & $0.034 *$ \\
\hline BIL (T) (mg/dl) & 0.359 & 0.051 \\
\hline BIL (d) (mg/dl) & 0.265 & 0.157 \\
\hline $\operatorname{ALT}(\mathrm{U} / \mathrm{I})$ & 0.035 & 0.855 \\
\hline $\mathrm{AST}(\mathrm{U} / \mathrm{I})$ & -0.063 & 0.740 \\
\hline ALK phos (U/L) & -0.128 & 0.500 \\
\hline S.ALB $(\mathrm{g} / \mathrm{dl})$ & -0.527 & $0.003 * *$ \\
\hline PT (second) & 0.407 & $0.035^{*}$ \\
\hline $\mathrm{PC}(\%)$ & -0.497 & $0.005^{* * *}$ \\
\hline INR & 0.410 & $0.030^{*}$ \\
\hline Alpha feto protein (ng/dl) & -0.189 & 0.316 \\
\hline PCR (IU/ml) & -0.200 & 0.747 \\
\hline Urea $(\mathrm{mg} / \mathrm{dl})$ & -0.800 & 0.200 \\
\hline Creat $(\mathrm{mg} / \mathrm{dl})$ & 0.034 & 0.858 \\
\hline Splenic span (mm) & 0.714 & $0.000^{* * *}$ \\
\hline Platelet count $\left(\mathrm{x} 10^{\wedge} 3 / \mathrm{cmm}\right) / \mathrm{spleen}$ diameter $(\mathrm{mm})$ ratio & -0.461 & $0.010^{*}$ \\
\hline
\end{tabular}

$* \mathrm{P}<0.05: \mathrm{S} ; * * \mathrm{P}<0.01: \mathrm{HS}$ 
Correlation between fibroscan $(\mathrm{KPa})$ and the studied parameters in group I revealed that there were statistically significant correlations between fibroscan and platelet count, prothrombin time, international normalized ratio and platelet count/spleen diameter ratio $(\mathrm{p}<0.05)$, while there were statistically non-significant correlations between fibroscan and the other studied parameters in group $\mathrm{I}(\mathrm{p}>0.05)$.

Table (3): Correlation between fibroscan and the studied parameters in group II.

\begin{tabular}{|c|c|c|}
\hline & \multicolumn{2}{|c|}{$\begin{array}{l}\text { Fibroscan } \\
(\mathbf{K P a})\end{array}$} \\
\hline & $\mathbf{r}$ & p-value \\
\hline Age (years) & 0.078 & 0.686 \\
\hline $\mathrm{Hb}(\mathrm{g} / \mathrm{dl})$ & 0.116 & 0.542 \\
\hline RBCs $\left(\mathrm{x} 10^{\wedge} 6 \mathrm{cell} / \mathrm{cmm}\right)$ & 0.254 & 0.183 \\
\hline WBCs $(/ \mathrm{cmm})$ & -0.102 & 0.590 \\
\hline PLTs $\left(x 10^{\wedge} 3 / \mathrm{cmm}\right)$ & -0.389 & $0.034 *$ \\
\hline BIL (T) (mg/dl) & 0.381 & $0.038^{*}$ \\
\hline BIL (d) (mg/dl) & 0.509 & 0.007 ** \\
\hline ALT (U/I) & -0.082 & 0.665 \\
\hline $\operatorname{AST}(\mathrm{U} / \mathrm{I})$ & 0.010 & 0.958 \\
\hline ALK phos (U/I) & 0.055 & 0.781 \\
\hline S.ALB $(g / d l)$ & -0.280 & 0.134 \\
\hline PT (second) & 0.416 & $0.022 *$ \\
\hline $\mathrm{PC}(\%)$ & -0.362 & $0.049^{*}$ \\
\hline INR & 0.372 & $0.043 *$ \\
\hline Alpha feto protein $(\mathrm{ng} / \mathrm{dl})$ & 0.175 & 0.356 \\
\hline PCR (IU/ml) & 0.048 & 0.869 \\
\hline Bilharzial titre & -0.005 & 0.981 \\
\hline Urea $(\mathrm{mg} / \mathrm{dl})$ & 0.056 & 0.713 \\
\hline Creat $(\mathrm{mg} / \mathrm{dl})$ & 0.052 & 0.783 \\
\hline Random blood suger & -0.147 & 0.448 \\
\hline Spleen span $(\mathrm{mm})$ & 0.743 & $0.000 * *$ \\
\hline $\begin{array}{l}\text { Platelet count }\left(\mathrm{x} 10^{\wedge} 3 / \mathrm{cmm}\right) / \text { spleen diameter }(\mathrm{mm}) \\
\text { ratio }\end{array}$ & $\mid-0.495$ & $0.005^{* *}$ \\
\hline
\end{tabular}

$* \mathrm{P}<0.05: \mathrm{S} ; * * \mathrm{P}<0.01: \mathrm{HS}$

Correlation between fibroscan and the studied parameters in group II revealed that there were statistically high significant correlations between fibroscan and direct bilirubin, spleen and platelet count / spleen diameter ratio $(\mathrm{p}<0.01)$. Correlation between fibroscan and the studied parameters in group II revealed that there were significant correlations between fibroscan and platelet count, total bilirubin, prothrombin time, PC, international normalized ratio $(\mathrm{p}<0.05)$. Correlation between fibroscan and the rest of the studied parameters in group II revealed that there were non-significant correlations ( $p>0.05$ ).

Table (4): Comparison between patients with no varices and patients with varices and also between patients with no varices and patients with large varices regarding fibroscan in both groups.

\begin{tabular}{|c|c|c|c|c|}
\hline \multirow[t]{2}{*}{ Group } & \multirow[t]{2}{*}{ Varices } & \multirow{2}{*}{$\begin{array}{c}\text { Fibroscan }(\text { KPa }) \\
(\text { Mean } \pm \text { SD })\end{array}$} & \multicolumn{2}{|c|}{$\begin{array}{c}\text { Independent } \\
\text { t-test }\end{array}$} \\
\hline & & & t & p-value \\
\hline \multirow{8}{*}{ Group I } & No varices $(\mathrm{N}=15)$ & $27.13 \pm 5.53$ & \multirow{2}{*}{11.235} & \multirow{2}{*}{$<0.001 * *$} \\
\hline & Varices $(\mathbf{N}=15)$ & $47.10 \pm 4.10$ & & \\
\hline & No $(\mathrm{N}=15)$ & $27.13 \pm 5.53$ & \multirow{2}{*}{2.949} & \multirow{2}{*}{$0.009 * *$} \\
\hline & Small $(\mathrm{N}=3)$ & $38.43 \pm 8.92$ & & \\
\hline & No varices $(\mathrm{N}=15)$ & $27.13 \pm 5.53$ & \multirow{2}{*}{5.359} & \multirow{2}{*}{$<0.001 * *$} \\
\hline & Large varices $(\mathrm{N}=12)$ & $45.79 \pm 12.30$ & & \\
\hline & Small varices $(\mathrm{N}=3)$ & $38.43 \pm 8.92$ & \multirow{2}{*}{0.963} & \multirow{2}{*}{0.353} \\
\hline & Large varices $(\mathrm{N}=12)$ & $45.79 \pm 12.30$ & & \\
\hline \multirow{8}{*}{ Group II } & No varices $(\mathrm{N}=7)$ & $19.50 \pm 4.77$ & \multirow{2}{*}{12.949} & \multirow{2}{*}{$<0.001 * *$} \\
\hline & Varices $(\mathrm{N}=23)$ & $38.95 \pm 3.33$ & & \\
\hline & No $(N=7)$ & $19.50 \pm 4.77$ & \multirow{2}{*}{2.113} & \multirow{2}{*}{0.060} \\
\hline & Small $(\mathrm{N}=\mathbf{5})$ & $28.7 \pm 10.2$ & & \\
\hline & No varices $(N=7)$ & $19.50 \pm 4.77$ & \multirow{2}{*}{3.051} & \multirow{2}{*}{$0.008^{* *}$} \\
\hline & Large varices $(\mathrm{N}=18)$ & $38.07 \pm 15.46$ & & \\
\hline & Small varices $(\mathrm{N}=\mathbf{5})$ & $28.7 \pm 10.2$ & \multirow{2}{*}{1.235} & \multirow{2}{*}{0.236} \\
\hline & Large varices $(\mathrm{N}=18)$ & $38.07 \pm 15.46$ & & \\
\hline
\end{tabular}

$* * \mathrm{P}<0.01: \mathrm{HS}$

Regarding fibroscan in both groups, the mean values of fibroscan were lower in patients without esophageal varices than patients with esophageal varices with statistically high significant differences $(\mathrm{p}<0.01)$.

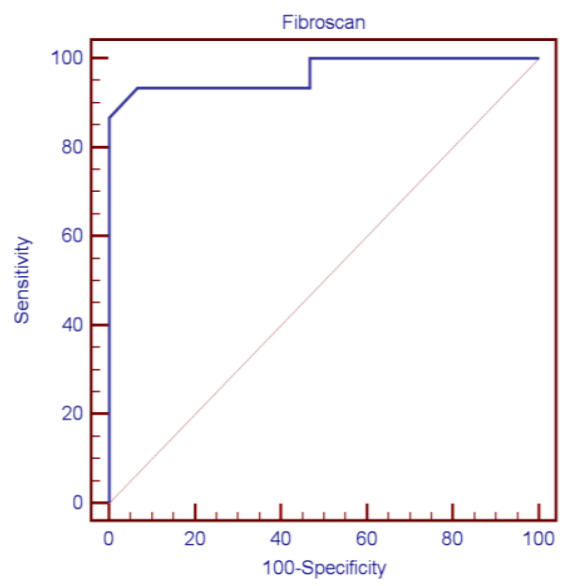

Figure (1): Receiver operating characteristics (ROC) curve to determine the best cut off value of fibroscan for OV (No\& OV) in group I. 
Table (5): Fibroscan cut off value for OV (No\& $\mathrm{OV})$ in group I

\begin{tabular}{|c|c|c|c|c|c|}
\hline $\begin{array}{c}\text { Fibroscan cut } \\
\text { off point }(\mathbf{K P a})\end{array}$ & $\begin{array}{c}\text { AUC } \\
(\mathbf{9 5 \%} \mathbf{C I})\end{array}$ & $\begin{array}{c}\text { Sensitivity } \\
\mathbf{( 9 5 \%} \mathbf{C I})\end{array}$ & $\begin{array}{c}\text { Specificity } \\
(\mathbf{9 5 \%} \text { CI })\end{array}$ & PPV & NPV \\
\hline 28 & $\begin{array}{c}0.967 \\
(88.6-100)\end{array}$ & $\begin{array}{c}93.33 \\
(85.4-98.3)\end{array}$ & $\begin{array}{c}93.33 \\
(85.4-98.3)\end{array}$ & 93.3 & 93.3 \\
\hline
\end{tabular}

Table (6): Fibroscan cut off value for large OV (No\& large OV) in group I.

\begin{tabular}{|c|c|c|c|c|c|}
\hline $\begin{array}{c}\text { Fibroscan cut off } \\
\text { point } \\
\text { (KPa) }\end{array}$ & $\begin{array}{c}\text { AUC } \\
(95 \% \mathrm{CI})\end{array}$ & $\begin{array}{c}\text { Sensitivity } \\
(95 \% \mathrm{CI})\end{array}$ & $\begin{array}{c}\text { Specificity } \\
(95 \% \mathrm{CI})\end{array}$ & PPV & NPV \\
\hline 39.1 & 0.851 & 85.71 & 73.91 & 50.0 & 94.4 \\
\hline
\end{tabular}

AUC: Area under the curve, CI: Confidence interval, PPV: positive predictive value, NPV: Negative predictive value

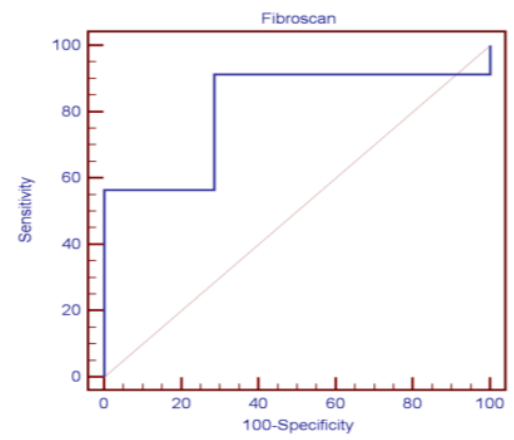

Figure (3): Receiver operating characteristics (ROC) curve to determine the best cut off value of fibroscan for OV (No\& OV) in group II.

Table (7): Fibroscan cut off value for OV (No\& $\mathrm{OV})$ in group II.

\begin{tabular}{|c|c|c|c|c|c|}
\hline $\begin{array}{c}\text { Fibroscan cut } \\
\text { off point (KPa) }\end{array}$ & $\begin{array}{c}\text { AUC } \\
(95 \% \mathrm{CI})\end{array}$ & $\begin{array}{c}\text { Sensitivity } \\
(95 \% \mathrm{CI})\end{array}$ & $\begin{array}{c}\text { Specificity } \\
(95 \% \mathrm{CI})\end{array}$ & PPV & NPV \\
\hline 21 & 0.814 & $\begin{array}{c}91.30 \\
(72.8-85.6)\end{array}$ & $\begin{array}{c}71.43 \\
(86.7-98.4)\end{array}$ & 91.3 & 71.4 \\
\hline
\end{tabular}

AUC: Area under the curve, CI: Confidence interval, PPV: positive predictive value, NPV: Negative predictive value

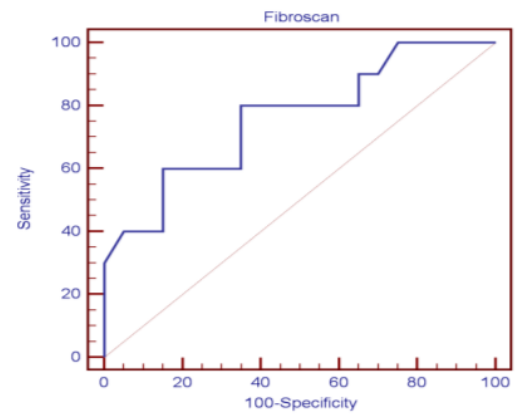

Figure (4): Receiver operating characteristics (ROC) curve to determine the best cut off value of fibroscan for large OV (No\& large OV) in group II.
Table (8): Fibroscan cut off value for large OV (No\& large OV) in group II.

\begin{tabular}{|c|c|c|c|c|c|}
\hline Cut off point (KPa) & $\begin{array}{c}\text { AUC } \\
(95 \% \mathrm{CI})\end{array}$ & $\begin{array}{c}\text { Sensitivity } \\
(95 \% \mathrm{CI})\end{array}$ & $\begin{array}{c}\text { Specificity } \\
(95 \% \mathrm{CI})\end{array}$ & PPV & NPV \\
\hline 26.4 & $\begin{array}{c}0.760 \\
(71.3-82.9)\end{array}$ & $\begin{array}{c}80.00 \\
(74.1-92.2)\end{array}$ & $\begin{array}{c}65.00 \\
(60.5-72.1)\end{array}$ & 53.3 & 86.7 \\
\hline
\end{tabular}

AUC: Area under the curve, CI: Confidence interval, PPV: positive predictive value, NPV: Negative predictive value

\section{DISCUSSION}

In Egypt the situation is quite worse. Chronic hepatitis c virus (HCV) is one of the top five leading causes of death in Egypt with a prevalence of $14.7 \%{ }^{(8)}$.

The presence of both HCV and Schistosomiasis is of significant concern as patients with coinfections have been shown to have higher HCV RNA titers, increased histological activity, greater incidence of cirrhosis/hepatocellular carcinoma and higher mortality rates than patients suffering from single infections ${ }^{(9)}$.

Contemporarily, liver stiffness measurement using FibroScan (EchoSens, Paris, France) was generated, which is painless, rapid (done at less than five minutes) and easy to perform at the bedside with immediate results. It examines a volume of the liver that is 100 times bigger than a biopsy sample and is therefore far more representative of the hepatic parenchyma. FibroScan generates an elastic wave using a vibrator applied to the intercostal spaces at the level of the right lobe of the liver and measures the propagation velocity of the shear wave, which is directly related to liver stiffness ${ }^{(\mathbf{1 0})}$.

This study was designed to evaluate transient elastography (a non-invasive technique); in the prediction and determination of the grade of esophageal varices in egyptian cirrhotic patients due to chronic hepatitis $\mathrm{C}$ virus infection with or without bilharziasis.

After approval of ethical committee of Al-Azhar school of medicine, this study was conducted on sixty Egyptian patients. An informed consent was obtained from all enrolled patients. Patients proved to have other chronic liver diseases e.g. hepatitis B virus $(\mathrm{HBV})$ were excluded. Furthermore patients with BMI $>35$, moderate and tense ascites, history of upper gastro-intestinal tract (GIT) bleeding or hepatocellular carcinoma were also excluded. All patients underwent through history taking, complete physical examination, body mass index estimation, complete liver profile (including ALT, AST, prothrombin time and concentration, bilirubin total and direct, serum albumin), renal function tests, CBC, IHA test for bilharziasis, serum HCV RNA count by PCR, HBs Ag, ANA, ESR, serum iron and serum 
ceruloplasmin. Abdominal ultrasonography, FibroScan and upper GIT endoscopy were done. Regarding fibroscan, group I had a higher mean $(37.12 \mathrm{KPa})$ with a high statistically significant difference than group II $(28.76 \mathrm{KPa})$ (table 1) $(\mathrm{p}<0.01)$. This could be explained by the effect of the previous exposure to schistosoma on fibroscan as this may impair the performance of fibroscan especially in F2 and F3 fibrosis stages and this was in agree with Esmat et al. ${ }^{(11)}$.

On the other hand, Reis and Ouma ${ }^{(12)}$ and Kamal et al. ${ }^{(13)}$ reported that there was significant increase in the progression rate of fibrosis in chronic HCV patients coinfected with Schistosoma compared to the HCV monoinfection group. But and Blanton et al. ${ }^{(14)}$ concluded that schistosomal hepatic affection does not alter or interfere with the assessment of fibrosis in mixed HCV-schistosomal liver affection.

These differences may be attributed to several factors such as duration of schistosomal infection, frequency of exposure to schistosomal infection and whether the patient has received treatment or not ${ }^{(\mathbf{1 4})}$.

Regarding fibroscan and the studied parameters in group I (table 2) revealed that there were statistically significant correlations between fibroscan and splenic span, prothrombin time and INR. There were statistically significant negative correlations between fibroscan and serum albumin, prothrombin concentration, platelets count and platelets count/spleen diameter ratio. These results were in agree with Kim et al. ${ }^{(15)}$

These findings were mainly attributed due to the effect of the advanced fibrosis state that was associated with decreased blood supply to the liver, decreased liver function and platelets count. Moreover increased fibrosis state of the liver leads to increase of the portal pressure and subsequently increase of the splenic size. These findings was explained by Gressner and Weiskirchen ${ }^{(16)}$, who reported that fibrosis is the common consequence of chronic liver injury due to various etiologies, subsequently leading from injury to inflammation to liver scarring. However, during recent decades of intensive experimental research it became evident that fibrogenesis is a complex wound-healing process that requires the interaction of several cell types that become triggered by a broad spectrum of cytokines, chemokines, and non peptide mediators including reactive oxygen species, lipid mediators, and hormones. Progressive fibrosis is linked to architectural changes of the liver with increased stiffness favoring portal hypertension with loss of functional parenchyma, it may advance to end-stage cirrhosis, and it provides a microenvironment that predisposes to liver cancer ${ }^{(\mathbf{1 7})}$.

The same results were obtained regarding correlations of fibroscan and the studied parameters in group II (table 3). Kim et al. ${ }^{(15)}$ mentioned that Liver stiffness (LS) values were positively correlated to fibrosis stages, ALT, spleen size and age, whereas platelet count, albumin and Prothrombin concentration were negatively correlated to LS values. Regarding fibroscan $(\mathrm{KPa})$ in group I patients in this study (table4), the mean value for patients with no varices (27.13) was lower than patients with varices (47.1) with statistically high significant difference $(p<0.01)$, the mean value for patients with no varices (27.13) was lower than patients with small varices (38.43) with statistically high significant difference $(p<0.01)$ and the mean value for patients with no varices (27.13) was lower than patients with large varices (45.79) with statistically high significant difference $(\mathrm{p}<0.01)$, and the mean values for patients with small esophageal varices (38.43) were lower than patients with large esophageal varices (45.79) with statistically non significant differences ( $p>0.05$ ). Regarding fibroscan (KPa) in group II patients in this study (table 4), the mean value for patients with no varices (19.5) was lower than patients with varices (38.95) with statistically high significant difference $(\mathrm{p}<0.01)$, the mean value for patients with no varices (19.5) was lower than patients with small varices (28.7) with statistically non significant difference (p> 0.05 ) and the mean value for patients with no varices (19.5) was lower than patients with large varices (38.07) with statistically high significant difference $(\mathrm{p}<0.01)$, and the mean values for patients with small esophageal varices (28.7) were lower than patients with large esophageal varices (38.07) with statistically non significant differences ( $p>$ 0.05 ).Regarding fibroscan in group I (table 5 and figure 1), at a cut off value $28 \mathrm{KPa}$ for detection of $\mathrm{OV}$, the sensitivity was $93.33 \%$ and the specificity was $93.33 \%$ and with positive predictive value of 93.3\% and negative predictive value of $93.33 \%$ and AUC of 0.967. At cut off value $39.1 \mathrm{KPa}$ for for detection of large OV (table 6 and figure 2), the sensitivity was $85.71 \%$ and the specificity was $73.91 \%$ with positive predictive value of $50 \%$ and negative predictive value of $94.4 \%$ and AUC of 0.851 . 
In a similar way Saad et al. ${ }^{(\mathbf{1 8 )}}$ assessed the role of LSM in 32 Egyptian patients for OV detection. It was found that the mean fibroscan value was higher in patients with $\mathrm{OV}$ than those without OV (49.4 versus $27 \mathrm{kPa}$; $\mathrm{p}=0.01$ ). Large varices had higher LS than small varices $(60.4$ versus $38.4 \mathrm{kPa} ; \mathrm{p}=0.002)$. At a cutoff of $29.7 \mathrm{kPa}$ they were able to predict OV presence while 38.2 $\mathrm{kPa}$ was the point at which presence of large varices could be predicted.

Sharma et al. ${ }^{(19)}$ investigated the utility of liver stiffness in evaluating OV presence in 200 consecutive cirrhotic patients. They reported that LS $\geq 27.3 \mathrm{kPa}$ had a sensitivity of $91 \%$, specificity of $72 \%$, PPV of $89 \%$, NPV of $76 \%$, and a diagnostic accuracy of $86 \%$ in predicting OV.

Fraquelli et al. ${ }^{(20)}$ reported that among 26 cirrhotic patients underwent diagnostic upper endoscopy, 11(42\%) had esophageal varices. The cutoff values of LS for presence of esophageal varices were $19 \mathrm{kPa}$. Moreover, studies carried out by Vizzutti et al. ${ }^{(7)}$ performed on 61 patients with HCVrelated chronic liver disease to detect the presence of esophageal varices; 30 of them had esophageal varices. At a cut-off value of $17.6 \mathrm{kPa}$, sensitivity was $90 \%$, specificity was $43 \%, 77 \%$ positive predictive value and $66 \%$ negative predictive value. Calvaruso et al. (21) reported that Echosens performed an analysis of the data using software that allows measurement of stiffness between 1.5 and $150 \mathrm{kPa}$. It was more accurate tool for predicting grade 2 or grade $3 \mathrm{OV}$. OVs were predicted with a cut off value of $17 \mathrm{kPa}$ by fibroscan. The corresponding AUROC was 0.82. Kazemi et al. ${ }^{(22)}$ performed his study on 165 cirrhotic patients, of which 74 had varices and 47 had large varices. They reported that for the detection of varices, the optimal Fibroscan cutoff was $13.9 \mathrm{kPa}$, with $95 \%$ sensitivity, $43 \%$ specificity, $57 \%$ positive predictive value and $91 \%$ negative predictive value. While for detection of large varices, cutoff was 19 $\mathrm{kPa}$, with $91 \%$ sensitivity, $60 \%$ specificity, $48 \%$ positive predictive value and $95 \%$ negative predictive value.

Regarding fibroscan in group II, at a cutoff value $21 \mathrm{KPa}$ for detection of OV (Table 7 and figure 3 ), the sensitivity was $91.3 \%$ and the specificity was $71.43 \%$ with positive predictive value of $91.3 \%$ and negative predictive value of $71.4 \%$ and AUC of 0.814 . At a cutoff value $26.4 \mathrm{KPa}$ for detection of large OV (Table 8 and figure 4), the sensitivity was $80 \%$ and the specificity was $65 \%$ with positive predictive value of
$53.3 \%$ and negative predictive value of $86.7 \%$ and AUC of 0.760. Hassan et al. ${ }^{\text {(23) }}$ assessed the role of LS in 65 Egyptian patients with liver cirrhosis as non invasive predictor of esophageal varices. They found that a LS cut-off $18.2 \mathrm{kPa}$ was predictive of OVs while $22.4 \mathrm{kPa}$ was the predictive point of large varices. They were also able to grade OVs: grade I $(22.37 \pm 6.97 \mathrm{kPa})$, grade II $(30.99 \pm 8.80 \mathrm{kPa})$ and grade III $(42.31 \pm 19.02 \mathrm{kPa})$. The cut off values in group II (HCV with bilharziasis) are near the values detected by Fraquelli et al. (20); Calvaruso et al. ${ }^{(21)}$; Vizzutti et al. ${ }^{(7)}$, but their studies were on HCV patients only. This could be explained by Abdel-Rahman et al. ${ }^{(24)}$; Ahmad et al. ${ }^{(25)}$ who reported that there were no signifcant difference between the $\mathrm{HCV}$ monoinfected and HCV/schistosomiasis coinfected patients in terms of fibrosis staging. Esmat et al. (11) demonstrated that previous exposure to Schistosoma was assumed to impair the performance of fibroscan, especially in F2 and F3 fibrosis stages. However, other studies showed a lack of enhancement of this pathology in schistosomal patients. This may be attributed to several factors such as duration of schistosomal infection, frequency of exposure to schistosomal infection and whether the patient has received treatment ${ }^{(\mathbf{1 4})}$.

\section{CONCLUSION}

Liver stiffness measurement by fibroscan is valuable in predicting the presence of esophageal varices and large esophageal varices in patients with post HCV liver cirrhosis with or without bilharziasis and may help to select patients for endoscopic screening. Fibroscan couldnot predict the grade of esophageal varices.

\section{REFERENCES}

1. Carbonell N, Pauwels A, Serfaty $L$ et al. (2004): Improves survival after variceal bleeding in patients with cirrhosis over the past two decades. Hepatology, 40: 652-659.

2. De Franchis R (2005): Evoloving consensus in portal hypertension. Report of the Baveno IV consensus workshop on methodology of diagnosis and therapy in portal hypertension. J Hepatol., 43: 167-176.

3. De Franchis R (2008): Non-invasive (and minimally invasive) diagnosis of oesophageal varices. Journal of Hepatology, 49: 520-7.

4. Stokkeland K, Brandt L, Ekbom A et al. (2006): Improved prognosis for patients hospitalized with esophageal varices in Sweden 1969-2002. Hepatology, 43: 500-505. 
5. Foucher J, Chanteloup E, Vergniol J et al. (2006): Diagnosis of cirrhosis by transient elastography $\left(\right.$ FibroScan $\left.^{\circledR}\right)$ : A prospective study. Gut, 55: 403-8.

6. Bloom $S$, Kemp W, Lubel J (2015): Portal hypertension: pathophysiology, diagnosis and management. Intern Med J., 45(1): 16-26.

7. Vizzutti F, Arena U, Romanelli RG et al. (2007): Liver stiffness measurement predicts severe portal hypertension in patients with HCVrelated cirrhosis. Hepatology, 45: 1290-1297.

8. Miller FD and Abu-Raddad LJ (2010): Evidence of intense ongoing endemic transmission of hepatitis $\mathrm{C}$ virus in Egypt. Proceedings of the National Academy of Sciences of the United States of America, 107: 14757-62.

9. Kamal SM, Rasenack JW, Bianchi L et al. (2001): Acute hepatitis $\mathrm{C}$ without and with schistosomiasis: correlation with hepatitis Cspecific CD4(+) T-cell and cytokine response. Gastroenterology, 121: 646-656.

10. Castera L (2012): Noninvasive methods to assess liver disease in patients with hepatitis B or C. Journal of Gastroenterology, 142(6): 1293-302.

11. Esmat G, Elsharkawy A, El Akel W et al. (2013): Fibroscan of chronic HCV patients coinfected with schistosomiasis. Arab Journal of Gastroenterology, 14: 109-112.

12. Reis MG and Ouma JH (2002): Populationbased differences in Schistosoma mansoni and hepatitis C-induced disease. J Infect Dis., 185(11): 1644-9.

13. Kamal SM, Graham CS, He Q et al. (2004): Kinetics of intrahepatic hepatitis $\mathrm{C}$ virus (HCV)-specific CD4+ Tcell responses in HCV and Schistosoma mansoni coinfection: relation to progression of liver fibrosis. J Infect Dis., 189: 1140-1150.

14. Blanton RE, Salam EA, Ehsan A et al. (2005): Schistosomal hepatic fibrosis and the interferon gammareceptor: a linkage analysis using single-nucleotide polymorphic markers. Eur J Hum Genet., 13: 660-668.

15. Kim SU, Jang HW, Cheong JY et al. (2011): The usefulness of liver stiffness measurement using FibroScan in chronic hepatitis $\mathrm{C}$ in South Korea: A multicenter, prospective study. Journal of Gastroenterology and Hepatology, 26: 171-8.
16. Gressner AM and Weiskirchen $R$ (2006): Modern pathogenetic concepts of liver fibrosis suggest stellate cells and TGF-beta as major players and therapeutic targets. J Cell Mol Med., 10: 76-99.

17. Trautwein C, Friedman SL, Schuppan D, Pinzani M. (2015): Hepatic fibrosis: concept to treatment. J Hepatol., 62(1): S15-S24.

18. Saad Y, Said M, Idris MO et al. (2013): Liver stiffness measurement by FibroScan predicts the presence and size of esophageal varices in Egyptian patients with HCV related liver cirrhosis. Journal of Clinical and Diagnostic Research, 7: 2253-7.

19. Sharma P, Kirnake V, Tyagi $P$ et al. (2013): Spleen stiffness in patients with cirrhosis in predicting esophageal varices. Am J Gastroenterol., 108(7): 1101-7.

20. Fraquelli M, Giunta M, Pozzi R et al. (2014): Feasibility and reproducibility of spleen transient elastography and its role in combination with liver transient elastography for predicting the severity of chronic viral hepatitis. Journal of Viral Hepatitis, 21: 90-8.

21. Calvaruso V, Bronte F, Conte E et al. (2013): Modified spleen stiffness measurement by transient elastography is associated with presence of large oesophageal varices in patients with compensated hepatitis $\mathrm{C}$ virus cirrhosis. Journal of Viral Hepatitis, 20: 867-74.

22. Kazemi F, Kettaneh A, N'Kontchou G et al. (2006): Liver stiffness measurement selects patients with cirrhosis at risk of bearing large ooesophageal varices. J Hepatol., 45: 230-235.

23. Hassan EM, Omran DA, El Beshlawey ML et al. (2014): Can transient elastography, Fib-4, Forns Index, and Lok Score predict esophageal varices in HCV-related cirrhotic patients? Journal of Gastroenterology and Hepatology, 37: 58-65.

24. Abdel-Rahman M, El-Sayed M, El Raziky M, et al. (2013): Coinfection with hepatitis C virus and schistosomiasis: Fibrosis and treatment response. World J Gastroenterol., 19(17): 2691-2696.

25. Ahmed L, Salama H, Ahmed R et al. (2009): Evaluation of Fibrosis Sero-Markers versus Liver Biopsy in Egyptian Patients with Hepatitis C and/or NASH and/or Schistosomiasis. PUJ., 2: 67-76. 